\title{
PENGARUH MODEL PEMBELAJARAN GENERATIF TERHADAP PEMAHAMAN KONSEP FISIKA POKOK BAHASAN BUNYI PESERTA DIDIK MTS AL-HIKMAH BANDAR LAMPUNG
}

\author{
Irwandani $^{1}$, Sani Rofiah ${ }^{2}$ \\ 1,2 Program Studi Pendidikan Fisika, FTK IAIN Raden Intan Lampung; e-mail: dirwansurya @ yahoo.co.id
}

Diterima: 3 Agustus 2015 Disetujui: 11 Oktober 2015. Dipublikasikan: Oktober 2015

\begin{abstract}
Abstact: This study aims to find and describe how much influence of generative learning models in class VIII students MTs Al-Hikmah Bandar Lampung. The research method used quasi experiment with Pretest-Posttest Control Group design. The research sample is divided into two classes, namely experimental and control class. The learning in experimental class uses a generative learning model while the control class uses the conventional learning model. Based on the result of the research, it can be concluded that the understanding of learners concept using generative learning model is higher compared with the understanding of learners concept using conventional learning model.
\end{abstract}

\begin{abstract}
Abstrak: Penelitian ini bertujuan untuk mengetahui dan mendeskripsikan seberapa besar pengaruh model pembelajaran generatif pada peserta didik kelas VIII MTs Al-Hikmah Bandar Lampung. Metode penelitian menggunakan kuasi eksperimen dengan desain Pretest-Posttest Control Group Design. Sampel penelitian terbagi dalam dua kelas, yaitu kelas eksperimen dan kelas kontrol. Kelas eksperimen menggunakan pembelajaran dengan model pembelajaran generatif sementara kelas kontrol menggunakan model pembelajaran konvensional. Berdasarkan hasil penelitian diperoleh kesimpulan bahwa pemahaman konsep peserta didik yang menggunakan model pembelajaran generatif lebih tinggi dibandingkan dengan pemahaman konsep peserta didik yang menggunakan model pembelajaran konvensional.
\end{abstract}

Kata kunci: model pembelajaran generatif, pemahaman konsep

\section{PENDAHULUAN}

Proses belajar mengajar di kelas dapat mempengaruhi mutu pendidikan. Kegiatan belajar mengajar merupakan bagian dari kegiatan yang paling pokok dalam proses pendidikan sekolah. Pada kegiatan pembelajaran, terdapat dua hal yang menentukan keberhasilan yaitu pengaturan proses belajar mengajar, dan pengajaran itu sendiri. Keduanya saling ketergantungan satu sama lain, sehingga dapat menciptakan suasana belajar yang memungkinkan peserta didik untuk belajar. Hal tersebut merupakan titik awal keberhasilan dalam kegiatan belajar.

Penggunaan model pembelajaran akan mempengaruhi proses pembelajaran. Pendidik yang menggunakan model pembelajaran bervariasi akan memiliki pemahaman konsep yang baik apabila pemahaman konsepnya telah tertanam dengan baik tentunya akan mengakibatkan hasil belajar yang baik pula. Model pembelajaran adalah kerangka konseptual yang melukiskan prosedur yang sistematis dalam mengorganisasikan pengalaman belajar 
untuk mencapai tujuan belajar tertentu, dan berfungsi sebagai pedoman bagi para perancang pembelajaran dan para pengajar dalam merencanakan aktivitas belajar mengajar (Shoimin, 2014).

Fakta yang terjadi menunjukan bahwa tidak sedikit dari peserta didik masih memiliki kemampuan yang rendah dalam memecahkan masalahmasalah fisika dan keterlibatan aktif dalam pembelajaran (Duit et al., 2010; Van Dat, 2012). Hal tersebut berpengaruh terhadap hasil belajar peserta didik. Di lapangan, kurangnya aktivitas siswa saat mengikuti pelajaran menjadi suatu permasalahan tersendiri. Siswa menjadi pasif karena hanya bertindak sebagai pendengar saja. Guru masih menjadi pemeran utama dalam kegiatan pembelajaran. Konsep yang diberikan oleh gurupun kurang dipahami oleh siswa (Ismawati, 2011). Oleh karena itu, perlunya upaya peningkatan kualitas pembelajaran di sekolah. Salah satu upaya memperbaiki kualitas belajar Peserta Didik di dalam kelas adalah orientasi pembelajaran yang semula berpusat pada guru (teacher-centered) beralih berpusat pada murid (student centered). Untuk itu, guru harus memilih suatu model pembelajaran yang sesuai sehingga situasi kelas lebih kondusif agar proses pembelajaran dapat berlangsung sesuai dengan tujuan yang diharapkan. Tujuan pembelajaran fisika di SMP/MTs lebih dikembangkan pada pemahaman konsep IPA khususnya fisika terutama dalam materi Bunyi serta aspek-aspek lainnya yang membangun penerapan konsep tersebut. Jika pemahaman konsep telah tertanam dan teraplikasi langsung dalam kehidupan nyata, maka bagaimanapun bentuk dari soal yang berbeda ketika dihadapi oleh peserta didik akan mudah dalam penyelesaiannya.

Berdasarkan hasil observasi penulis dengan melihat nilai semester ganjil peserta didik mata pelajaran IPA khususnya fisika kelas VIII pada salah satu MTs di Bandar Lampung, dapat dikatakan sebagian besar peserta didik masih belum mencapai kriteria baik. penulis hanya menyajikan sampel dua kelas dikarenakan keterbatasan yang dimiliki penulis.

Berdasarkan data yang diperoleh penulis pada saat observasi diketahui bahwa kriteria ketuntasan minimal (KKM) mata pelajaran IPA khususnya fisika pada sekolah tersebut adalah adalah 70. Melihat dari data yang penulis terima maka, terlihat bahwa masih banyak peserta didik yang tidak mencapai KKM, walaupun sudah ada sebagian yang sudah mencapai KKM.Untuk peserta didik yang sudah mencapai KKM sebanyak $43 \%$ dari seluruh jumlah peserta didik pada dua kelas tersebut.Artinya masih ada lebih dari $60 \%$ peserta didik yang belum mencapai KKM.Salah satu penyebabnya dikarenakan kurangnya pemahaman konsep peserta didik pada pelajaran IPA khususnya fisika.hasil wawancara penulis dengan seorang guru mata pelajaran IPA khususnya fisika pada salah satu MTs di Bandar Lampung, rendahnya pemahaman konsep tersebut dikarenakan beberapa hal diantaranya adalah masih digunakanya model pembelajaran konvensional yang dalam pelaksanaan 
pembelajaran masih berasal dari satu arah, yaitu guru. Seperti yang telah penulis kemukakan di atas. Faktor lainnya adalah kurangnya kemampuan peserta didik untuk mengaitkan konsep sebelumnya yang masih berhubungan dengan konsep baru yang sedang diajarkan.

Solusi yang dapat dilakukan untuk mengatasi masalah tersebut adalah dengan menerapkan model pembelajaran yang disesuaikan dengan konsep yang lebih tepat dengan kondisi yang ada di kelas, dan dipadukan dengan metode pembelajaran yang lain untuk memperbaiki pemahaman konsep Peserta Didik. Oleh karena itu, dalam memilih suatu model pembelajaran guru harus memiliki pertimbangan-pertimbangan seperti materi pelajaran, jam pelajaran, tingkat perkembangan kognitif Peserta Didik, lingkungan belajar, dan fasilitas penunjang yang tersedia, sehingga tujuan pembelajaran yang telah ditetapkan dapat tercapai.

Salah satu model pembelajaran yang memberikan dampak positif bagi pemahaman konsep peserta didik dalam proses pembelajaran adalah model pembelajaran Generatif. Berdasarkan kajian teori yang dilakukan penulis, menunjukkan bahwa model pembelajaran generatif mampu dalam meningkatkan kemampuan berpikir tingkat tinggi dan kemampuan pemecahan masalah peserta didik (Alba et al., 2013; Sugilar, 2013).

Oleh karena itu, berdasarkan kajian tersebut diperlukan penelitian untuk membuktikan kebenaran dari kajian konsep yang telah penulis lakukan.

\section{LANDASAN TEORI}

\section{Model Pembelajaran}

Model pembelajaran adalah suatu perencanaan atau suatu pola yang digunakan sebagai pedoman dalam merencanakan pembelajaran di kelas atau pembelajaran dalam tutorial (Trianto, 2012). Model pembelajaran bisa diartikan sebagai kerangka konseptual yang melukiskan prosedur yang sistematis dalam mengorganisasikan pengalaman belajar untuk mencapai tujuan belajar tertentu, dan berfungsi sebagai pedoman bagi para perancang pembelajaran dan para pengajar dalam merencanakan aktivitas belajar mengajar.

Menurut Rusman (2013) model pembelajaran merupakan pola umum prilaku pembelajaran untuk mencapai tujuan pembelajaran yang diharapkan. Model-model pembelajaran akan terus berkembang sesuai dengan perkembangan kebutuhan peserta didik. Guru yang profesional dituntut mampu pengembangkan model pembelajaran, baik teoritik maupun praktek, yang meliputi aspek-aspek, konsep, prinsip, dan teknik.

\section{Model Pembelajaran Generatif}

Model Pembelajaran generatif (generatif learning) pertama kali diperkenalkan oleh Osborne dan Wittrock pada tahun 1985. Dasar dari model pembelajaran generatif adalah konstruktivisme dengan sintaks orientasi-motivasi, pengungkapan idekonsep awal, tantangan, dan 
restrukturisasi sajian konsep, aplikasi, rangkuman, evaluasi dan refleksi.

Intisari dari pembelajaran generatif adalah otak tidak menerima informasi dengan pasif, melainkan justru dengan aktif mengkonstruksi suatu interpretasi dari informasi tersebut dan kemudian membuat kesimpulan. Melalui pembelajaran generatif akan dapat menciptakan suasana belajar yang menyenangkan, dimana peserta didik dapat dengan bebas mengungkapkan ide-ide yang dimilikinya, pertanyaan-pertanyaan, maupun masalah-masalah, sehingga dapat menciptakan suasana belajar yang lebih efektif, dan penuh makna. Langkah-langkah dalam pembelajaran generatif dapat memberikan kesempatan kepada peserta didik untuk dapat merespon dan menyelesaikan masalah secara bebas, kreatif, dan lebih menyenangkan. Peserta didik membentuk pengetahuannya melalui interaksi dengan bahan yang dipelajari atau pengalaman baru yang dialaminya.

Dalam model pembelajaran generatif, pengetahuan yang dimiliki oleh peserta didik adalah hasil dari pada aktivitas yang dilakukan oleh pelajar tersebut dan bukan pengajaran yang diterima secara pasif. Menurut Shoimin (2014), tahapan-tahapan dalam pembelajaran generatif adalah sebagai berikut:

a. Tahap orientasi, yaitu Peserta didik diberi kesempatan untuk membangun kesan mengenai konsep yang sedang dipelajari dengan mengaitkan materi dengan pengalaman sehari-hari. Tujuannya agar peserta didik termotivasi mempelajari konsep tersebut.

b. Tahap pengungkapan ide, yaitu peserta didik diberi kesempatan untuk mengemukakan ide mereka mengenai konsep yang dipelajari. Pada tahap ini peserta didik akan menyadari bahwa ada pendapat yang berbeda mengenai konsep tersebut.

c. Tahap tantangan dan restrukturisasi, yaitu guru menyiapkan suasana dimana peserta didik diminta membandingkan pendapatnya dengan pendapat peserta didik yang lain dan mengemukakan keunggulan dari pendapat mereka tentang konsep yang dipelajari. Kemudian guru mengusulkan peragaan demonstrasi untuk menguji kebenaran pendapat peserta didik. Pada tahap ini diharapkan peserta didik sudah mulai mengubah struktur pemahaman mereka (conceptual change).

d. Tahap penerapan, yaitu kegiatan dimana peserta didik diberi kesempatan untuk menguji ide alternatif yang mereka bangun untuk menyelesaikan persoalan yang bervariasi. Peserta didik diharapkan mampu mengevaluasi keunggulan konsep baru yang diakembangkan. Melalui tahap ini guru dapat meminta peserta didik menyelesaikan persoalan baik yang sederhana maupun yang kompleks.

e. Tahap melihat kembali, yaitu peserta didik diberi kesempatan untuk mengevaluasi kelemahan 
dari konsepnya yang lama. Peserta didik juga diharapkan dapat mengingat kembali apa saja yang mereka pelajari selama pembelajaran.

Berdasarkan tahapan model pembelajaran tersebut, maka karakteristik model generative learning dibandingkan dengan model lain yaitu:

a. Model ini menekankan pada motivasi, perhatian dan konsepsi awal siswa.

b. Model ini menekankan pada pengalaman belajar siswa.

c. Model ini menekankan kepada penggabungan konsep baru dengan konsep yang dimiliki siswa sebelumnya.

d. Pada tahap akhir dari model generative learning, konsep baru yang diperoleh siswa diingatkan kembali

Adapun yang menjadi kelebihan model pembelajaran generatif adalah sebagai berikut :

a. Memberikan kesempatan kepada peserta didik untuk mengungkapkan pemikiran, pendapat, dan pemahamanya terhhadap konsep.

b. Melatih peserta didik untuk mengkomunikasikan konsep.

c. Melatih peserta didik untuk menghargai gagasan orang lain.

d. Memberikan kesempatan kepada peserta didik untuk peduli terhadap konsepsi awalnya (terutama peserta didik yang miskonsepsi). Peserta didik diharapkan menyadari miskonsepsi yang terjadi dan bersedia memperbaikinya.

e. Memberikan kesempatan kepada peserta didik untuk mengkonstruksi pengetahuanya sendiri.

f. Dapat menciptakan suasana kelas yang aktif karena peserta didik dapat membandingkan gagasanya dengan gagasan peserta didik lainya serta intervensi guru.

g. Guru mengajar menjadi kreatif dalam mengarahkan peserta didiknya untuk mengkonstruksi konsep yang akan dipelajari.

h. Guru menjadi teerampil dalam memahami pandangan peserta didik dan mengorganisasi pembelajaran.

Sementara itu, yang menjadi kelamahan penggunaan model pembelajaran generatif sebagai berikut:

a. Peserta didik yang pasif merasa diteror untuk mengonstruksi konsep.

b. Membutuhkan waktu yang relatif lama

c. Bagi guru yang tidak berpengalaman akan merasa kesulitan untuk mengorganisasi pembelajaran.

\section{Penerapan Model Generative Learning di Kelas}

Penerapan model pembelajaran Generative learning di kelas dapat dijabarkan dalam kegiatan berikut: 
Tabel 1. Penerapan model generative learning di kelas

\begin{tabular}{|c|c|c|}
\hline $\begin{array}{c}\text { Tahap } \\
\text { Pembelajaran }\end{array}$ & Kegiatan Guru & Kegiatan Siswa \\
\hline \multirow[t]{3}{*}{ Tahap 1: Orientasi } & $\begin{array}{l}\text { Memberikan aktivitas } \\
\text { melalui demonstrasi yang } \\
\text { dapat merangsang siswa } \\
\text { untuk melakukan eksplorasi. }\end{array}$ & $\begin{array}{l}\text { Mengorientasi pengetahuan, ide atau } \\
\text { konsepsi awal yang diperoleh dari } \\
\text { pengalaman sehari-hari atau } \\
\text { diperoleh dari pembelajaran pada } \\
\text { tingkat kelas sebelumnya. }\end{array}$ \\
\hline & $\begin{array}{l}\text { Mendorong dan merangsang } \\
\text { siswa untuk mengemukakan } \\
\text { pendapat/ide serta } \\
\text { merumuskan hipotesis. }\end{array}$ & $\begin{array}{l}\text { Mengutarakan ide-ide dan } \\
\text { merumuskan hipotesis. }\end{array}$ \\
\hline & $\begin{array}{l}\text { Membimbing siswa untuk } \\
\text { mengklasifikasi pendapat. }\end{array}$ & $\begin{array}{l}\text { Melakukan klasifikasi pendapat/ide- } \\
\text { ide yang telah ada. }\end{array}$ \\
\hline \multirow[t]{3}{*}{$\begin{array}{l}\text { Tahap 2: } \\
\text { Pengungkapan Ide }\end{array}$} & $\begin{array}{l}\text { Membimbing dan } \\
\text { mengarahkan siswa untuk } \\
\text { menentukan konteks } \\
\text { permasalahan berkaitan } \\
\text { dengan ide siswa yang } \\
\text { kemudian dilakukan } \\
\text { pengujian. }\end{array}$ & $\begin{array}{l}\text { Menetapkan konteks permasalahan, } \\
\text { memahami, mencermati } \\
\text { permasalahan sehingga siswa menjadi } \\
\text { familier terhadap bahan yang } \\
\text { digunakan untuk mengeksplorasi } \\
\text { konsep. }\end{array}$ \\
\hline & $\begin{array}{l}\text { Membimbing siswa } \\
\text { melakukan proses sains, } \\
\text { yaitu menguji (melalui } \\
\text { percobaan) sesuatu. }\end{array}$ & $\begin{array}{l}\text { Melakukan pengujian, berpikir apa } \\
\text { yang terjadi, menjawab pertanyaan } \\
\text { berhubungan dengan konsep. } \\
\text { Memutuskan dan menggambarkan } \\
\text { apa yang siswa ketahui tentang } \\
\text { kejadian. } \\
\text { Mengklarifikasi ide dalam konsep. }\end{array}$ \\
\hline & $\begin{array}{l}\text { Menginterpretasi respon } \\
\text { siswa. } \\
\text { Menginterpretasi dan } \\
\text { menguraikan ide siswa. }\end{array}$ & $\begin{array}{l}\text { Mempresentasikan ide ke dalam } \\
\text { kelompok dan juga forum kelas } \\
\text { melalui diskusi. }\end{array}$ \\
\hline $\begin{array}{l}\text { Tahap 3: } \\
\text { Tantangan }\end{array}$ & $\begin{array}{l}\text { Mengarahkan dan } \\
\text { memfasilitasi agar terjadi } \\
\text { pertukaran ide antar siswa. } \\
\text { Menjamin semua ide siswa } \\
\text { dipertimbangkan. } \\
\text { Membuka diskusi. } \\
\text { Melakukan demonstrasi jika } \\
\text { diperlukan. } \\
\text { Menunjukkan bukti } \\
\text { ilmuwan. }\end{array}$ & $\begin{array}{l}\text { Memberikan pertimbangan ide } \\
\text { kepada siswa yang lain, dan semua } \\
\text { siswa dalam kelas. } \\
\text { Menguji validitas ide/ pendapat } \\
\text { dengan mencari bukti. } \\
\text { Membandingkan ide ilmuwan dengan } \\
\text { kelas. }\end{array}$ \\
\hline $\begin{array}{l}\text { Tahap 4: } \\
\text { Penerapan }\end{array}$ & $\begin{array}{l}\text { Membimbing siswa } \\
\text { merumuskan permasalahan } \\
\text { yang sangat sederhana. } \\
\text { Membawa siswa } \\
\text { mengklarifikasi ide baru. } \\
\text { Membimbing siswa agar } \\
\text { mampu menggambarkan } \\
\text { secara verbal penyelesaian } \\
\text { problem. }\end{array}$ & $\begin{array}{l}\text { Menyelesaikan problem praktis } \\
\text { dengan menggunkanan konsep dalam } \\
\text { situasi yang baru. } \\
\text { Menerapkan konsep yang baru } \\
\text { dipelajarai dalam berbagai konteks } \\
\text { yang berbeda. } \\
\text { Mempresentasikan penyelesaian } \\
\text { masalah di hadapan teman. Diskusi } \\
\text { dan debat tentang penyelesaian }\end{array}$ \\
\hline
\end{tabular}




\begin{tabular}{lll}
\hline $\begin{array}{c}\text { Tahap } \\
\text { Pembelajaran }\end{array}$ & \multicolumn{1}{c}{ Kegiatan Guru } & \multicolumn{1}{c}{ Kegiatan Siswa } \\
\hline & $\begin{array}{l}\text { Ikut terlibat dalam } \\
\text { merangsang dan } \\
\text { berkontribusi ke dalam } \\
\text { diskusi untuk menyelesaikan } \\
\text { permasalahan }\end{array}$ & $\begin{array}{l}\text { masalah, mengkritisi dan menilai } \\
\text { penyelesaian masalah. } \\
\text { Menarik kesimpulan akhir. }\end{array}$ \\
& & \\
& $\begin{array}{l}\text { Memberikan pertanyaan } \\
\text { untuk merangsang konsep } \\
\text { Tahap 5: Melihat } \\
\text { kembali }\end{array}$ & $\begin{array}{l}\text { Mengingat kembali konsep yang } \\
\text { sudah dipelajari. }\end{array}$ \\
& & \\
\hline
\end{tabular}

\section{Pemahaman Konsep}

Pemahaman terhadap konsep merupakan bagian yang penting dalam proses pembelajaran dan memecahkan masalah, baik di dalam proses belajar itu sendiri maupun dalam lingkungan keseharian. Kemampuan memahami konsep menjadi landasan untuk berpikir dalam menyelesaikan berbagai persoalan. Siswa dikatakan memahami bila mereka dapat mengkonstruksi makna dari pesan-pesan pembelajaran, baik yang bersifat lisan, tulisan ataupun grafis, yang disampaikan melalui pengajaran, buku, atau layar komputer (Anderson dan Krathwohl, 2001).

Kemampuan memahami ini mencakup kemampuan untuk mengubah satu bentuk menjadi bentuk lain, misalnya dari bentuk verbal menjadi bentuk rumus, dapat menangkap arti dari informasi yang diterima, misalnya dapat menafsirkan bagan, diagram atau grafik, meramalkan berdasarkan kecenderungan tertentu dan sebagainya.

Anderson dan Krathwohl (2001) membagi 7 (tujuh) proses-proses kognitif dalam aspek memahami meliputi menafsirkan, mencontohkan, mengklasifikasikan, merangkum, menarik inferensi, membandingkan dan menjelaskan. Dalam penelitian ini hanya diambil 6 (enam) indikator pemahaman konsep, yaitu:

a. Menafsirkan (interpreting). Indikator menafsirkan tercapai apabila siswa dapat mengubah informasi dari satu bentuk ke bentuk lainnya, seperti mengubah kata-kata atau konsep menjadi suatu persamaan, mengubah katakata ke dalam bentuk gambar, grafik, dan sebaliknya.

b. Mencontohkan (exemplifying). Proses kognitif mencontohkan terjadi manakala siswa memberikan contoh tentang konsep atau prinsip umum (Anderson dan Krathwohl, 2001). Mencontohkan bisa juga berarti mengilustrasikan dan memberi contoh terhadap konsep yang telah dipelajari.

c. Mengklasifikasikan (classifying). Mengklasifikasikan bisa juga disebut mengelompokkan atau mengkategorikan. Indikasi tercapainya proses kognitif mengklasifikasikan terjadi apabila siswa mampu mengetahui sesuatu seperti contoh maupun peristiwa 
termasuk ke dalam suatu kategori tertentu, seperti konsep, prinsip atau hukum tertentu.

d. Menarik Inferensi / menyimpulkan (inferring). Proses kognitif menarik inferensi menyertakan proses menemukan pola dalam sejumlah contoh (Anderson dan Krathwohl, 2001). Proses ini cukup dekat dengan kegiatan menyimpulkan. Siswa dikatakan bisa menarik inferensi apabila ia mampu mengabstraksi sebuah konsep atau prinsip yang menerangkan contohcontoh atau kejadian-kejadian dengan mencermati ciri-cirinya serta mampu menarik hubungan diantara ciri-ciri dari rangkaian contoh-contoh atau kejadiankejadian tersebut (Krathwohl, 2002).

e. Membandingkan (comparing). Membandingkan dikenal juga dengan nama lain mengontraskan, memetakan dan mencocokkan. Proses kognitif membandingkan melibatkan proses mendeteksi persamaan dan perbedaan antara dua atau lebih objek, peristiwa, ide, masalah, atau situasi, seperti menentukan bagaimana suatu peristiwa terkenal menyerupai peristiwa yang kurang terkenal (Anderson dan Krathwohl, 2001). Membandingkan bisa berupa pencarian korespondensi atau pasangan satu-satu suatu objek.

f. Menjelaskan (explaining). Menjelaskan bisa disebut juga dengan membuat model. Proses kognitif menjelaskan berlangsung ketika siswa dapat membuat dan menggunakan model sebab-akibat dalam sebuah sistem (Anderson dan Krathwohl, 2001)

\section{METODE PENELITIAN}

Metode penelitian ini menggunakan metode kuasi eksperimen atau eksperimen semu. Dengan desain Control Group PretestPostest yang digambarkan dalam tabel berikut: (Arikunto, 2013)

Tabel 2. Desain penelitian

\begin{tabular}{cccc}
\hline Kelas & Pretest & Perlakuan & Postest \\
\hline $\mathrm{E}$ & $\mathrm{T}_{1}$ & $\mathrm{X}$ & $\mathrm{T}_{2}$ \\
\hline $\mathrm{K}$ & $\mathrm{T}_{1}$ & $\mathrm{Y}$ & $\mathrm{T}_{2}$ \\
\hline
\end{tabular}

Ket:

$\mathrm{E}=$ Kelas eksperimen

$\mathrm{K}=$ Kelas kontrol

$\mathrm{X}=$ Model pembelajaran generatif

$\mathrm{Y}=$ Model pembelajaran konvensional $\mathrm{T}_{1}=$ Soal pretest pemahaman konsep

$\mathrm{T}_{2}=$ Soal postest pemahaman konsep

Populasi dalam penelitian ini adalah seluruh peserta didik kelas VIII MTs Al-Hikmah Bandar Lampung Tahun ajaran 2014/2015.Adapun sampel yang digunakan dipilih dengan teknik purposive sampling sehingga diperoleh dua kelompok untuk kelas eksperimen dan kelas kontrol.

Prosedur dari penelitian ini mengacu pada empat tahapan utama, meliputi studi pendahuluan, persiapan, pelaksanaan dan analisis hasil dan penyusunan laporan. Kegiatan studi pendahuluan dilakukan untuk memperoleh gambaran aktual tentang permasalahan pembelajaran fisika di kelas.Setelah diperoleh permasalahan melalui kegiatan observasi, kemudian dilakukan analisis terhadap masalah 
tersebut. Langkah selanjutnya adalah melakukan studi literatur untuk mencari dan menyusun langkah penyelesaian masalah tersebut.

Setelah studi pendahuluan dilakukan, peneliti kemudian melakukan tahap persiapan.Kegiatan utama yang dilakukan dalam tahapan ini adalah menyusun perangkat pembelajaran, instrumen penelitian, dan melakukan ujicoba.Penyusunan perangkat pembelajaran terdiri dari rencana pelaksanaan pembelajaran (RPP), lembar kerja siswa, dan soaluntuk kegiatan diskusi dan segala perlengkapannya.Selanjutnya peneliti membuat instrumen penelitian yang terdiri atas soal-soal pemahaman konsep berbentuk pilihan ganda yang disusun berdasarkan indikatorindikator yang disesuaikan dengan kurikulum.

Setelah disusun, instrumen penelitian kemudian dikonsultasikan dan diberi penilaian atau judgement oleh dosen ahli.Selanjutnya, instumen diujicobakan terlebih dahulu untuk melihat kualitas dan kelayakannya.Adapun instrumen yang layak untuk dijadikan instrumen penelitian berjumlah 20 instrumen dari total 23 instrumen yang diujicobakan.

Tahap selanjutnya adalah pelaksanaan.Setelah semua perangkat dan instrumen telah siap, maka dilakukan pelaksanaan penelitian. Kegiatan penelitian dilakukan di kelas eksperimen dan kontrol. Dalam tahap ini dilakukan juga kegiatan pengumpulan data dengan teknik pengumpulan berupa observasi, dokumentasi, wawancara dan tes pemahamankonsep untuk enam aspek pemahaman konsep.

Selanjutnya, tahap terakhir adalah tahap analisis dan penyusunan laporan.Dalam tahap analisis ini dilakukan berbagai teknik analisis data dengan menghitung gain yang dinormalisasi (N-gain) dari nilai tes awal (pretest) dan tes akhir (postest) terhadap pemahaman konsep peserta didik baik yang kelas eksperimen maupun kelas kontrol.Selain itu, dilakukan pula analisis terhadap hasilhasil observasi, wawancara dan dokumentasi yang dilakukan selama kegiatan penelitian.Data-data tersebut kemudian diuji secara statistik dan ditelaah untuk kemudian dianalisis.Hasil analisis digunakan untuk menguji hipotesis yang diajukan dalam penelitian.Hasil penelitian kemudian disusun sedemikian rupa sesuai dengan kaidah penyusunan karya ilmiah.

\section{HASIL DAN PEMBAHASAN}

Hasil utama yang diperoleh dari penelitian ini adalah pemahaman konsep peserta didik setelah diterapkan model pembelajaran generatif. Berikut disajikan hasil pretest dan postest dari kelas eksperimen:

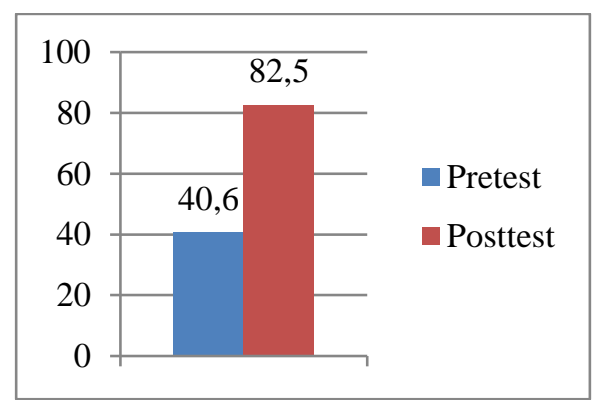

Gambar 1. Grafik hasil rata-rata pretest dan posttest kelas eksperimen 
Dari grafik di atas diketahui bahwa hasil rata-rata pretest yang diperoleh oleh kelas eksperimen adalah sebesar 40,6 dan hasil rata-rata posttest yang diperoleh oleh kelas eksperimen adalah sebesar 82,5.

Adapun untuk kelas kontrol diperoleh hasil yang disajikan dalam grafik sebagai berikut:

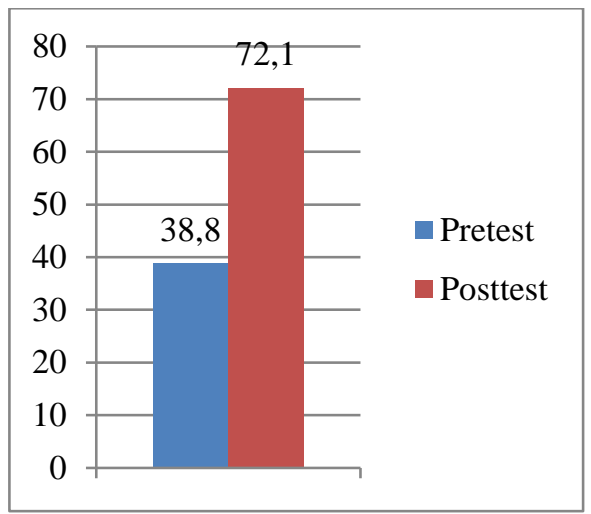

Gambar 2. Grafik hasil rata-rata pretest dan posttest kelas kontrol

Dari grafik di atas diketauhi bahwa hasil rata-rata pretes yang diperoleh oleh kelas kontrol adalah sebesar 38,8 dan hasil rata-rata posttes yang diperoleh oleh kelas kontrol adalah sebesar 72,1 .

Adapun berbandingan $\mathrm{N}$-gain antara kelas eksperimen dan kontrol adalah sebagai berikut.

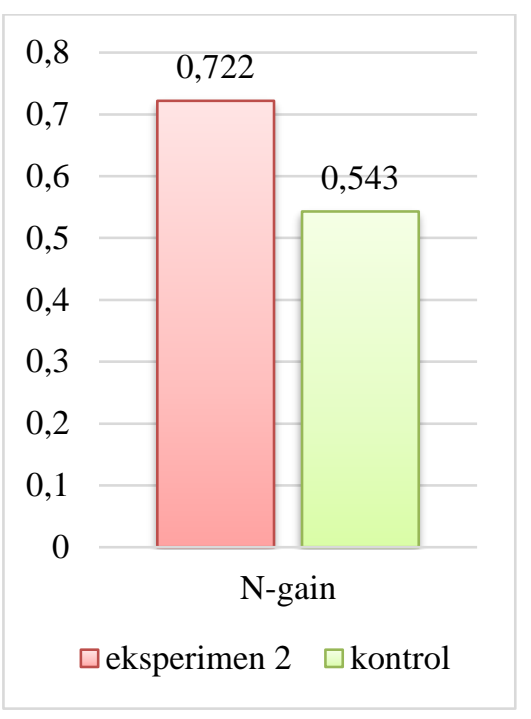

Gambar 3. Grafik rata-rata perbandingan $\mathrm{N}$-gain kelaseksperimen dan kelas control

Dari grafik di atas, diketahui bahwa rata-rata $N$-gain pemahaman konsep peserta didik yang menggunakan model pembelajaran generatifsebesar 0,722 , sedangkan ratarata $N$-gain pemahaman konsep peserta didik dengan pembelajaran konvensional sebesar 0,543.

Dalam penelitian ini, ada enamaspek pemahaman konsep yang menjadi objekpengamatan.Berikut disajikan rata-rata pemahaman konsep peserta didik kelas eksperimen dan kontrol berdasarkan aspek pemahaman yang diamati. 


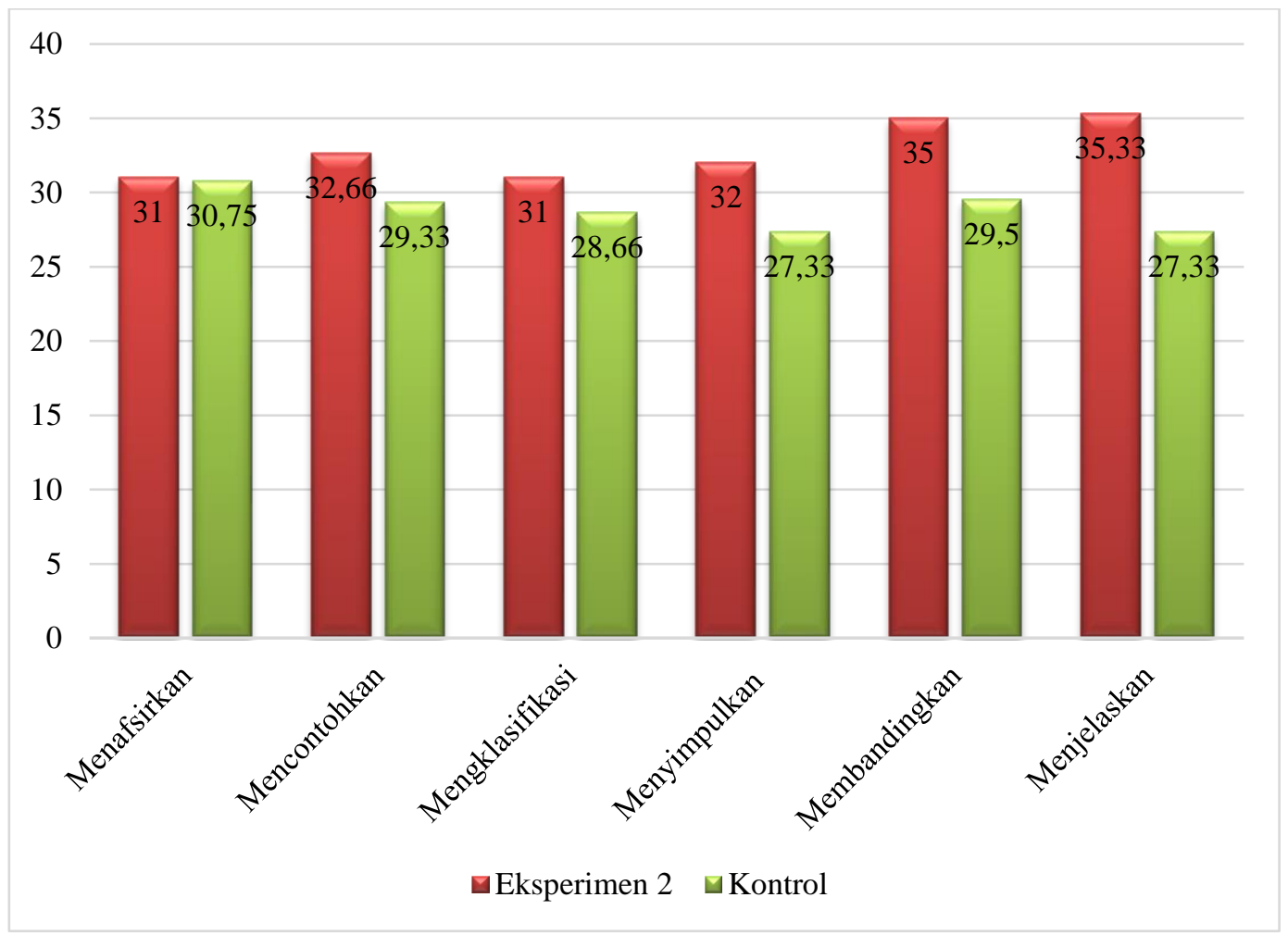

Gambar 4. Grafik perbandingan rata-rata pretasi belajar setiap jenjang kognitif.

Berdasarkan grafik di atas, dan "menjelaskan". Hal ini dikarenakan diketahui bahwa rata-rata pemahaman pada model generatif terdapat tahapan konsep peserta didik pada aspek menafsirkan sebesar 31,0 pada aspek mencontohkan sebesar 32,66 pada aspek mengklasifikasi sebesar 31,0 pada aspek menyimpulkan sebesar 32,0 pada aspek membandingkan sebesar 35,0 dan pada aspek menjelaskan sebesar 35,33. Sedangkan rata-rata pemahaman konsep peserta didik pada kelas kontrol untuk aspek menafsirkan sebesar 30,75 pada aspek mencontohkan sebesar 29,33 pada aspek mengklasifikasi sebesar 28,66 pada aspek menyimpulkan sebesar 27,33 pada aspek membandingkan sebesar 29,5 dan pada aspek menjelaskan sebesar 27,33.

Dua aspek mengalami capaian tertinggi yaitu aspek "membadingkan" yang mampu mengoptimalkan dua aspek tersebut, yaitu tahapan dan mengungkapkan ide dan tahap penerapan. Kedua tahapan tersebut berperan cukup baik dalam meningkatkan kemampuan pemahaman peserta didik dikedua aspek tertinggi tersebut. Peserta didik dilatihkan untuk menjelaskan ide mereka dan membandingkan dengan ide-ide dari temannya yang lain.

Secara umum, hasil penelitian ini membuktikan bahwa penggunaan model pembelajaran generatif yang disesuaikan dengan materi yang akan diajarkan dapat memberikan hasil pemahaman konsep yang berbeda pada peserta didik dibandingkan dengan 
model pembelajaran yang biasa dilakukan sehari-hari.

Kemudian untuk menguji seberapa besar pengaruh model terhadap pemahaman konsep peserta didik, dalam penelitian ini terlebih dahulu dilakukan uji prasyarat untuk analisis data. Uji prasyarat analisis data dalam penelitian ini menggunakan uji normalitas dan homogenitas. Untuk uji normalitas menggunakan uji liliefors sedangkan uji homogenitas menggunakan uji fishers.

Perhitungan uji normalitas nilai pretest peserta didik pada kelas eksperimen didapatkan hasil hitung sebesar 0,1232 dan tabel sebesar 0,1402, dan untuk hasil perhitungan normalitas pada kelas kontrol didapatkan hasil hitung sebesar 0,1319 dan tabel sebesar 0,1353. Kemudian untuk perhitungan uji normalitas nilai posstest peserta didik pada kelas eksperimen didapatkan hasil lhitung sebesar 0,1308 dan ltabel sebesar 0,1402 , dan untuk hasil perhitungan normalitas pada kelas kontrol didapatkan hasil lhitung sebesar 0,1319 dan ltabel sebesar 0,1076. Berdasarkan uraian di atas dapat diketahui bahwa data pretest dan posttest peserta didik dari masing-masing kelas tersebut berdistribusi normal.

Hasil perhitungan uji homogenitas data pretest posttest kelas eksperimen dan kelas kontrol diperoleh Fhitung pretest yaitu sebesar 1,44 sedangkan Fhitung posttest sebesar 1,61 dengan Ftabel sebesar 1,67. Dari uraian diatas dapat disimpulkan bahwa data tersebut homogen.
Setelah data diketahui berdistribusi normal dan homogen untuk menguji hipotesismenggunakan uji t (uji beda). Berdasarkan hasil perhitungan diperoleh dan dinyatakan bahwa terdapat pengaruh model pembelajaran generatif terhadap pemahaman konsep peserta didik.

\section{SIMPULAN DAN SARAN}

\section{Simpulan}

Berdasarkan hasil pengujian hipotesis diperoleh kesimpulan bahwa model pembelajaran generatif dapat lebih meningkatkan pemahaman konsep peserta didik dibandingkan dengan model pembelajaran konvensional. Adapun pemahaman konsep yang dapat ditingkatkan dengan baik terutama pada aspek "membandingkan" dan "menjelaskan". Hal ini dikarenakan pembelajaran generatif mampu melatihkan dua aspek tersebut dengan baik.

\section{Saran}

Berdasarkan pembahasan dan simpulan, peneliti memberikan saran sebagai berikut:

1. Guru dan peserta didik perlu melakukan simulasi terlebih dahulu untuk membiasakan tahapan dari model pembelajaran generatif.

2. Dalam pembelajaran jumlah anggota tiap-tiap kelompok hendaknya tidak terlalu banyak, agar tiap kelompok bisa efektif.

3. Diperlukan kreatifitas dan kejelian guru terutama dalam mengungkap dan menggali ide-ide siswa. 


\section{DAFTAR PUSTAKA}

Alba, F. M., Chotim, M., \& Junaedi, I. (2013). Keefektifan Model Pembelajaran Generatif dan MMP Terhadap Kemampuan Pemecahan Masalah. Kreano, Jurnal Matematika KreatifInovatif, 4(2), 131-137.

Anderson, L. W., Krathwohl, D. R., Airasian, P. W., Cruikshank, K. A., Mayer, R. E., Pintrich, P. R., Raths, J., Wittrock, M. C. (2001). Kerangka Landasan untuk Pembelajaran, Pengajaran, dan Asesmen: Revisi Taksonomi Pendidikan Bloom. Yogyakarta: Pustaka Pelajar.

Arikunto, Suharsimi. (2013). Prosedur Penelitian Suatu Pengembangan Praktik. Jakarta: PT. Rineka cipta.

Duit, R., Niedderer, H., \& Schecker, H. (2010). Teaching Physics. In S. K. Abell \& N. G. Lederman (Eds.), Handbook of research on science education. New Jersey: Routledge.

Ismawati, N., \& Hindarto, N. (2011). Penerapan model pembelajaran kooperatif dengan pendekatan struktural two stay two stray untuk meningkatkan hasil belajar siswa kelas x SMA. Jurnal Pendidikan Fisika Indonesia, 7(1).

Trianto. (2012). Model Pembelajaran Terpadu. Jakarta: Bumi Aksara.

Rusman. (2013). Model-Model pembelajaran. Jakarta: Rajawali Pers.
Shoimin, Aris. (2014). 68 Model Pembelajaran Inovatif Dalam Kurikulum 2013. Yogyakarta: Ar-Ruzz Media.

Sugilar, H. (2013). Meningkatkan Kemampuan Berpikir Kreatif dan Disposisi Matematik Siswa Madrasah Tsanawiyah Melalui Pembelajaran Generatif. Infinity Journal, 2(2), 156-168.

Van Dat, T. (2012). Predicting the Attitudesand Self-esteem Grade 9th Lower Secondary School Students Towards Mathematics From their Perception of the Classroom Learning Environment. World Journal of Education, 2(4), 34 - 44. doi: 10.5430/wje.v2n4p34 